\title{
Consumer Intention to Adopt Digital Financial Services in Egypt: An Extended Technology Acceptance Model'
}

\section{Dr. Doaa Mohamed Ismael}

Lecturer of Economics, Faculty of

Commerce and Business Administration,

Future University

Doaa.ismael@fue.edu.eg

ORC ID:0000-0002-5559-6919

\author{
Samar Salah Ali \\ Assistant Lecturer of Finance, Faculty of \\ Commerce and Business Administration, \\ Future University \\ Samar.salah@fue.edu.eg
}

\section{Dr.Safwat Adel Elsharkawi}

Lecturer of Management, Faculty of

Management Sciences, October

University for Modern Sciences and Arts

Selsharkawi@msa.edu.eg

ORC ID:0000-0003-4768-1117

\begin{abstract}
Digital finance is a key driver of financial inclusion in Egypt and an important channel of financial service delivery. Digital finance creates new opportunities to unbanked population, increase effectiveness by facilitating individuals' daily financial transactions, and offer wider financial choices for start-ups. However, achieving higher digital financial inclusion is not determined only by the service provider, but also by consumers' acceptance to use digital financial services which is a salient driver to the success of digital finance adoption. This study contributes to the literature by being one of the pioneer studies that identify the factors influencing consumer intention to use not only internet banking but all digital financial services in Egypt. Extended technology acceptance model (TAM) was used that incorporates, perceived usefulness, perceived ease of use, perceived risk, perceived cost, government support, and trust as main factors. A questionnaire was designed and distributed electronically to anyone that may use digital financial service. A valid 167 eligible responses were obtained. PLS - SEM method was utilized where measurement model is analysed to test the validity and reliability of the instruments and then hypothesis was tested using structural equation model. The results revealed that perceived usefulness (PU) and trust (TRU) have positive significant impact on consumers' intention (INT) to use digital financial services while perceived ease of use (PEU), perceived Risk (PR), and Perceived cost (PC) have no effect on consumers' intention. Furthermore, regarding government support (GS), the results were surprising where no impact on consumers' usage intention was found. However,
\end{abstract}

${ }^{1}$ Received in 1 September 2021, accepted in 25 November 2021. 
perceived risk and government support have indirect effect on consumer's intention through their effect on consumers' trust, thus TRU is said to play a significant intermediary role.

Keywords: Digital Finance; consumer acceptance, technology acceptance model, adoption intention, financial inclusion

\section{I- INTR ODUCTION}

Financial inclusion, defined as the ease of access to and the usage of traditional financial services by all people is one of the main cornerstones of sustainable development for any country since low level of financial inclusion hinders economic growth and hence sustainable development (Burgess and Pande, 2005 and Beck et al., 2007). Increase access to financial services and markets is set as one of the main UN sustainable development goals, and thus promoting greater financial inclusion is one of the main challenges that developing countries must meet as 90 percent of the unbanked people are settled in these countries (Demirguc - kunt et al., 20I8).

Digital finance is a form of financial services carried out over smart phones, computers, connected to the internet (Manyika et al., 2016). Similarly, different scholars defined digital finance as financial applications offered by any organization that offers financial services to the community over the Internet. It encompasses range of interactive financial services from peer-to-peer lending, electronic payment, and crowd funding (Gomber et al., 20I7; Ozili, 20I8; and Huang \& Zheng, 2020). These finance-related applications designed and carried out by Fin Tech corporations and advanced financial service providers (Gomber et al., 20I7). Hence, digital finance involves using new information technologies to transform the traditional way of providing banking and other financial services into new digitalized one. This, in turn will potentially engage involuntary excluded people from using and accessing traditional financial services and thus achieving greater financial inclusion (Sun, 2018 and Ozili, 20I8). Accordingly, digital financial inclusion (DFI) can be defined as "digital access to and use of formal financial services by the excluded and underserved population" (CGAP, 2015 and Lauer \& Lyman, 2015). More specifically, it's about accessing and using the same traditional bank based financial services through digital channels without the need for direct interactions. 
Digital Finance have several benefits such as increasing financial inclusion, utilizing financial services in non-financial industries, offering inexpensive, wider choices, suitable and safe banking service to mass customers in developing countries and increasing efficiency of operations. It can also provide financial services that can be cheaper, more convenient, and tailored to the users' needs, therefore offering opportunities to improve consumer welfare and support their financial stability and finally facilitate the digital transformation of cash-based transactions (World Bank, 20I4). Furthermore, digital finance has a vital role in enhancing the gross domestic product (GDP) levels, particularly of digital economies through offering an easy access to enormous financial services to customers as well as small, medium, and large firms (Manyika et al., 2016). Furthermore, digital finance enhances bank performance which in return increases its profitability on the long run

On the other hand; customers will be able perform all their financial transactions online and thus save time, effort, and money (Scott, Van Reenen and Zachariadis, 2017) through using several new channels such as internet banking applications, Point of Sales Machines (POS), online payment gateways, e-wallets and ATMs rather than only using conventional channels by visiting bank branches which incur higher transaction costs compared to digital financial services (DFS) (Maragaoda, 2019 and Ennew et al., 2002).

Digital finance is a key driver of financial inclusion in Egypt and is considered an important channel of financial service delivery especially to unbanked population. According to the World Bank's Global Findex database, as of 2017 , only $33 \%$ of the adult population in Egypt has a bank account which is much lower compared to other developing countries. Thus, using information technology to deliver the traditional financial service is the only way. However, Egypt is still in its early stage of digitalization as its classified as one of the countries that has low digital financial inclusion level with DFI of 0.3I (Ismail \& Ali, 202I). The low level of digital financial inclusion can be attributed to different reasons; Egypt's strong cash culture, limited accessibility to digital financial services, lack of awareness of digital financial services, low digital skills, and lack of trust in using digital financial applications (Ismael \& Ali, 202I). Moreover, Individual acceptance to use new technology is a key factor to its success (Sharma and Govindaluri, 2014). Therefore, consumer acceptance to use new information technologies is a crucial 
issue to the success of digital finance and the adoption of internet banking and other digital financial application (Pikkarainen et al., 2004; AbuShanab and Pearson, 2007; Yiu et al., 2007\& Edgar, 2007; Yousafzai \& Yani-de-Soriano, 20I2; Lema, 2017)

Although some empirical researches have been conducted to identify the factors influencing the adoption of internet banking in developing countries (Anandarajan et al., 2000; Ekin and Polaoglu, 200I; Malhotra and Singh, 2007; EL - Kasheir et al., 2009; Owoseni, 20I4), few studies took the attempt to discuss very limited factors in Egypt (Kamel \& Hassan, 2003; Metwally, 2013; El Aziz et al., 20I4) and other Arab countries (AbuShanab \& Pearson, 2007; Al-Somali et al., 2009; Al-Ghaith et al., 20IO; Nasri, 20II; Riffai, et al., 2012; Al-Ajam, \& Nor, 2015). Thus, more research must be done in this area. Moreover, to the best of the authors' knowledge, there is no study that addressed the factors influencing the adoption of different digital financial services in Egypt, from consumer behaviour. The few studies done in this area mainly discussed internet banking only, however, digital financial services have much wider scope than internet banking only. This study aims to fill in this gap. Thus, this empirical study contributes to the literature by being the first to identify the factors influencing consumer acceptance to use not only to internet banking, but all digital financial services delivered in Egypt. To reach this objective, the study extends the original technology acceptance model (TAM) by incorporating the most significant variables that affect consumer intention to use new technologies in Egypt.

The rest of the paper is structured as follows. Section two discusses conceptual framework and literature review; section three discusses the data and methodology. Subsequently, section four and five reports the study empirical results and discussion. Conclusion is presented in section six while academic and managerial implications are highlighted in section seven. Finally, study limitations and future research are presented in section eight.

\section{2- CONCEPTUAL FRAMEWORK AND HYPOTHESIS DEVELOPMENT}

\section{2-i Technology Acceptance Model (TAM)}

The Theory of Reasoned Action (TRA 1986) is one of the most important theories used in explaining Behavioural beliefs that shape person's attitude and intention towards an objective (Fishbein \& Ajzen, 1975). However, the lack of 
measurement variables leads to the development of Technology Acceptance Model (TAM) as an extension to TRA model that adds additional measurable variables; perceived behavioural control variables (Davis, 1989). According to TAM, perceived usefulness (PU) and perceived ease of use (PEU) - salient drivers for TAM -significantly impact consumer's attitude and thus affecting his behavioural intention toward using new computer systems (Davis, 1989). Thus, TAM is seen by researchers as the most powerful model for explaining user's behavioural intentions and acceptance to use new information technologies in different countries (Venkatesh and Davis, 200o; Chan and Lu, 2004; Chiemeke et al., 2006; Masinge, 20Io; Lule and Omwansa, 2012; Lema, 2017).

Although TAM has enabled researchers to explain consumers' behavior towards new technology, however it has its own limitation (Venkatesh et al., 2003; Venkatesh and Bala, 2008; Lule and Omwansa, 2012; Al - Ajam and Md Nor, 2013). Scholars have found that the two specific constructs used in the original TAM are insufficient to explain consumer social behaviour towards using internet banking and other digital financial services. Thus, the original TAM model was adjusted and extended to be able to identify factors that can predict the accessibility of e-banking technology. Researchers extended the original TAM model by adding new constructs rather than perceived usefulness and ease of use that affect consumer's acceptance of new technologies such as design, quality of the service, personality, risk, perceived credibility, subjective norms, trust, and perceived enjoyment (Davis, 1989; Venkatesh and Davis, 2000; Venkatesh \& Bala 2008; Masinge, 20I0; Lai and Ahmed 20I4; Lai \& Zainal, 20I5; Lai, 2016; Lai, 20I8). Therefore, extended TAM model gained wide confirmation as one of the best models in explaining consumer's intention to use digital financial services and can be improved and specified according to the research questions (Venkatesh and Davis, 2000 and Hu et al., 2019).

Several empirical studies done on Africa used the extended TAM model to identify the factors influencing consumers' acceptance to use new digital financial services. Although most of the empirical studies found significant impact for perceived usefulness and perceived ease of use, perceived usefulness proved to have greater influence on consumer intention to use different digital financial services (Kamel \& Hassan, 2003; Sayid et al., 2012; Munir and Idrus, 2013; Aboelmaged and Gebba, 20I3; Metwally, 20I3; and El Aziz et al., 20I4). Other empirical studies 
identified lack of trust, perceived financial cost and perceived risk as main barriers to use digital financial services (Mayer et al., I995; Jarvenpaa et al., 2000; Lee, 2009; Bansal et al., 20Io; Dass and Pall, 20II; and Hanafizadeh et al., 20I4)

In this study, the extended TAM model is used to identify the factors influencing consumer acceptance to use digital financial services in Egypt. The factors examined are perceived usefulness (PU), Perceived ease of use (PEU), perceived risk (PR), perceived cost (PC), government support (GS) and Trust (TRU).

\section{2-2 Hy POThesis DeVelopment}

\section{2-2-I Per Ceived usefulness (PU) and Consumer Attitude}

Perceived usefulness - derived from traditional TAM model- explain the tendency of consumers to use new information technology only when they believe that it will improve their performance and work efficiency (Davis, 1989). In this research, perceived usefulness refers to the extent that consumers use new digital financial services if they believe that this new digital service can affect their performance positively. Many empirical studies found that perceived usefulness have a positive impact on consumers' behavioral intention to adopt online technologies and online banking (Chen and Ching, 2002; Chen et al., 2002; Heijden et al., 2003; Wang et al., 2003; Liao \& Wong, 2008; Widjana and Rachmat, 2oII; and Rusu and Shen, 20I2). In the context of digital financial services, perceived usefulness is a vital factor in determining consumers' acceptance to use digital financial services once its benefits are considered (Kleijnen et al., 2004; Luarn and Lin, 2005; and Wang et al., 2006). Thus, in the light of the previous literature the following hypothesis were developed in the context of digital financial services.

Hypothesis I $\left(H_{I}\right)$ : Consumers'perceived usefulness (PU) have positive impact on their attitude towards the adoption of digital financial services.

\section{2-2-2 Perceived Ease of Use (PEU), Perceived Usefulness (PU) and CONSUMER ATTITUDE}

Perceived ease of use is the second salient factor in the traditional TAM model affect consumers' attitude toward adoption of new technologies either directly or indirectly through its effect on PU (Davis, 1989; Venkatesh and Davis, 2000; and Aboelmaged and Gebba, 20I3). In this research, perceived ease of use (PEU) refers 
to how easy consumers can learn to use online payments gateways and mobile banking services. Many empirical studies in the field of banking had found a significant positive relation between perceived ease of use and consumers' attitude (ATT) toward adoption of digital financial services. (Akturan and Tezcan, 20I2; Munir and Idrus, 2013; Sayid et al., 2012; Aboelmaged and Gebba, 2013 and Al Ajam and $\mathrm{Md} \mathrm{Nor,} \mathrm{2013).} \mathrm{If} \mathrm{consumers} \mathrm{found} \mathrm{that} \mathrm{the} \mathrm{websites} \mathrm{and} \mathrm{applications}$ are clear, friendly, easy to operate without any complicated procedures, no mental effort is required and can easily interact with the system, then consumers will accept to use digital financial services (Chen et al., 2002; Heijden et al., 2003; Pikkarainen, 2004; Guriting and Ndubisi, 2006; Aboelmaged \& Gebba, 2013). Thus, according to the previous review of literature, the following two hypotheses were developed:

Hypothesis $2\left(\mathrm{H}_{2}\right)$ : Perceived Ease of Use (PEU) has positive impact on Consumer's attitude towards the adoption of digital financial

Hypothesis $3\left(H_{3}\right)$ : Consumers'perceived Ease of Use (PEU) has positive impact on Perceived Usefulness (PU)

\section{2-2-3 AtTItUdes (ATT) \& CONSUMERS' INTENTION (INT)}

Attitude refers to personal tendency to take a certain action based on user's subjective norms, while intention is defined as the consumer intention to use certain technology (Davis and Vakentesh, 1996). Attitude can significantly influence consumers' intention to use digital financial services where a positive attitude means consumers' will adopt these technologies while consumers with negative attitude will be uncertain to use digital financial services or not (Jaruwachirathanakul and Fink, 2005 and Ng \& Kwok; 2017). Many empirical studies in the field of $\mathrm{e}$ - business found that there is a significant positive relation between person's attitude and behavioral intention to use e - services (Lee, 2009; Aboelmaged \& Gebba, 2013; Md Nor and Pearson, 2008; George, 2002; Ng and Kwok, 2017, and Hu et al., 2019). Furthermore, Puschel et al., (2010) found that person's attitude has positive impact on their behavioral intention to use e banking services. Thus, the following two hypotheses were proposed:

Hypothesis $4\left(\mathrm{H}_{4}\right)$ : Consumers' attitude (ATT) and intention to use (INT) digital financial services are positively correlated. 


\section{2-2-4 TRUST (TRU) AND CONSUMER ATTITUDE}

Trust is a key factor that affect consumer's intention to adopt new technologies, beside Perceived usefulness, and Perceived Ease of Use (Goles et al., 2009). McKnight and Chervany, 2ooI defined trust as "consumer's cognitive beliefs that result from their inherited trust characteristics that affect their behaviour". Ennew and Sekhon (2007) viewed trust as "the willingness of consumers to accept vulnerability of trustee actions as their behavior assumed to be based on risk". In our research, Trust is defined as consumers' certainty that their financial information is secured while using digital financial services. Thus, Trust plays a significant role in convincing consumers to perform online financial transactions as more risk is involved compared to traditional finance (Yousafzai et al., 2003). In this context, if consumers' trust the e - service provider, uncertainty will decrease, leading to positive attitude towards adoption of digital financial services (Koksal, 2016). In other words, user's trust in e - service provider makes it much easier to encourage them to use new digital financial services. That's why its very important to examine the impact of trust on consumer's attitude towards new digital financial services (Mayer et al., I995; Teo \& Liu, 2007; Al - Ajam and Md Nor, 20I3; Hanafizadeh et al., 20I4; Hu et al., 2019).

Hypothesis 5 ( $\left.H_{5}\right)$ : Consumers' trust (TRU) of digital financial services bas a significant positive impact on their attitude towards the adoption or use of digital financial services

\section{2-2-s Per Ceived Risk (PR), Trust (TRU), and Consumer AtTitude}

Bauer (1960) was the first to define the concept of perceived risk. It is defined as "a combination of uncertainty plus seriousness of outcome involved-associated with each category of product". Perceived risk was also defined in the field of marketing as "consumers' perception of uncertainty and adverse consequences of engaging in a purchase activity" (Pathak \& Pathak 2017). Perceived risk is considered one of the most important factors that affect consumers' decision in using digital finance. Many scholars viewed perceived risk as the main factor that is negatively related with consumer's acceptance to adopt new technology (Rotchanakitumnuai and Speece, 2003; Ndubisi and Sinti, 2006; Kesharwani and Bisht, 2012; Hu et al., 2019). In this research, perceived risk refers to the security and privacy risk consumers perceive when they use any digital financial service. Security risk refers 
to consumers' perception that e - service providers take all security measures such as; authentication and encryption that protect their personal data. Many empirical studies proved that if e - service providers use different security protection mechanisms; consumers will have a positive attitude towards the use of digital finance. Therefore, the more security measures taken, the higher the degree of consumers' trust in e - service providers and thus consumers' will have positive attitude towards the adoption of digital financial services (Friedman and Khan, 2000; Chellappa and Pavlou, 2002; and Cruz et al., 20IO).

Privacy risk refers to consumers' perception that e - service providers will protect their personal confidential private data during any online transaction and will never disclose such data (Kim et al., 2008). Many empirical studies found that if consumers are not confident that their sensitive personal data are secured from any hacking attempts, these threats will push them to opt out from performing any online financial transaction (Ndubisi and Jantan, 2003; Gerrard et al., 2006; Lee et al., 2007; Md Nor and Pearson, 2008; and Khedmatgozar et al., 2018). Therefore, perceived risk arises from uncertainty would have a negative impact on consumers' attitude towards the use of digital financial services (Jarvenpaa et al., 2000; Kesharwani and Bisht, 2012; and Bansal et al., 2010).

Furthermore, due to the characteristics of e - financial services, trust and risk are said to be negatively related. Empirical studies confirmed that trust in e commerce retailers reduce risks, as they believe that trustee's will never take any decisions that might affect their consumer's trust and security. Consumers assume that $\mathrm{e}$ - retailer they trust will never engage in any opportunistic behavior that might affect their trust in the future. Moreover, trust induce e - retailers to take positive actions to decrease uncertainty and other perceived risks related to internet infrastructure, and personal data security and hence trust has negative impact on different risks involved in any e - transaction. Therefore, consumer's trust in online payment gateways and $\mathrm{e}$ - banking institutions reduces perceived risks (Jarvenpaa et al., 2000; Kesharwani and Bisht, 20I2; Pikkarainen et al., 2004; Yousafzai, 2005; Lee et al., 2007; and Marakarkandy and Dasgupta; 2016). Thus, the following two hypotheses were developed:

Hypothesis $6\left(H_{6}\right)$ : Perceived Risk (PR) has negative significant impact on consumers' attitude towards the adoption of digital financial services. 
Hypothesis $7\left(\mathrm{H}_{7}\right)$ : Perceived Risk (PR) has negative significant impact on consumers' trust of digital financial services.

\section{2-2-6 Government SUPPORT (GS), TRUSt (TRU), and CONSUMER ATTITUDE}

Government Support is a key driver for technological innovation and is considered one of the most important determinants that influence consumers' intention to use internet banking (Jussawalla et al. 1992; Heng and Low 1993; Jaruwachirathanakul and Fink, 2005; and Hai and Kazmi, 2015). Government's support to e - services can increase the credibility and reliability of digital finance application and hence consumer acceptance to adopt new digital finance technologies (Tan and Teo, 2000 and Marakarkandy and Dasgupta; 2016). Government can support digital finance applications by investing heavily in ICT infrastructure which will influence positively consumer intention to perform online financial transactions (Chong and Ooi, 2008; Marakarkandy and Dasgupta; 2016). Different scholars in their empirical studies found that government support to internet banking through huge infrastructure investments has significant influence on user's intention to use online banking applications (Tan and Teo, 2000; Chong and Ooi, 2008; and Marakarkandy and Dasgupta; 2016).

The government role in encouraging people to move toward digitalization is not limited to ICT infrastructure investments; but also, in defining and implementing cybersecurity and e - commerce laws. These laws defined by the government and implemented under Central Banks supervision increase the credibility of all digital financial services and encourage potential consumers to accept and use such e services (Tan and Teo, 2000; Chang and Ooi, 2008; and Chong et al., 2010). Furthermore, Government support whether through infrastructure investments or cybersecurity laws is crucial to trust $\mathrm{e}$ - financial services and hence its adoption (Marakarkandy and Dasgupta; 2016). Therefore, the following hypothesis were developed

Hypothesis \& ( $\left.\mathrm{H}_{8}\right)$ : Government Support (GS) has a significant positive impact on consumers' attitude towards the adoption of digital financial services

Hypothesis $9\left(H_{g}\right)$ : Government Support (GS) has a significant positive impact on consumers' trust (TRU) of digital financial services. 


\section{2-2-7 Perceived Cost (PC) and Consumer Attitude}

In decision making process, consumers usually evaluate the service based on the expected costs and benefits involved in using such service. Therefore, the cost of using digital financial service is a prominent factor that influence consumer's intention to use digital financial services (Wang et al., 2006; Luarn and Lin, 2005; and Sripalawat et al., 20II). Perceived cost can be defined as the cost of adopting and using technology. In this research, perceived cost is the cost people believe they will incur while using digital financial services such as; mobile banking applications and online payment gateways (Luran and Lin, 2005; Gerrard et al., 2006; Black et al., 2012; Ramlugun and Issuree, 2014; and koksal, 2015). Kleijnen et al., 2004 argued that perceived cost is one of the main barriers that affect consumer's intention to use of e-banking services. In reviewing the literature, empirical studies revealed a negative relationship between cost and consumer's attitude towards the use of mobile banking (Cruz et al., 20Io; Wessels and Drennan, 20Io; and Luarn and Lin, 2005). Since perceived cost is one of the most important factors when using DFS, lowering the cost will most likely encourage more consumers to use these new innovative services. Hence, the following hypothesis was developed:

Hypothesis Io $\left(H_{I 0}\right)$ : Perceived Cost $(P C)$ has a significant negative impact on consumer's attitude towards the adoption of digital financial services.

The proposed model is shown in figure I:

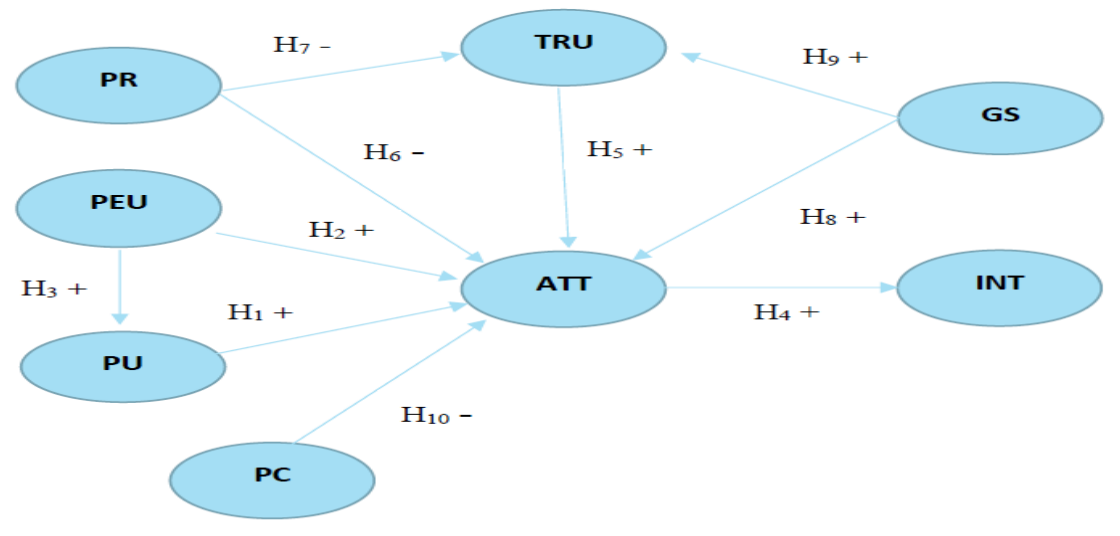

Figure I: Conceptual Model 


\section{3- ME'THODOLOGY}

\section{3-i Data Collection and Sample Characteristics}

The main objective of this study is to determine the key factors that affect consumers' acceptance of digital financial services in Egypt through analyzing their behavioural intention to use such technologies. Therefore, non-probability convenience sampling method was used in this research which is coherent with several previous studies analyzing internet banking adoption and other technology adoption (Luarn and Lin, 2005; Revels et al., 2010; Bebli, 20I2; Ramdhony and Munien, 20I3; Ramlugun and Issuree, 2014). The sample unit was anyone who might use digital financial services which is defined in this study as "the traditional financial services that can be accessed, used and delivered online" such as internet banking, mobile banking application, and other online payment gateways (MyFawry, Meeza, Vodafone Cash, Aman etc.).

The only criteria needed for participating in such study is to have access to the internet which is an appropriate method (Celik, 2008). Thus, online questionnaire has been designed using online google sheets. The questionnaire's URL was distributed using different social media tools to ensure that the sample is representative. Total 167 questionnaires were returned and used for the analysis. In this paper, Smart PLS 3.0 were used in data analysis. Regarding respondents' profile, such as gender, age, income, employment, and other characteristics are shown in table I. $98 \%$ of the respondents were female and $69 \%$ were male, most of the respondents lie in the age group $26-35$ with average age of 31 years. This indicates that new technologies are always accepted by this age group as they can easily adopt new technologies. Thus, the study sample was reasonable. Moreover, it is worth to note that 6I of the respondents held a master's degree of more. Finally; $60.9 \%$ of the respondents use digital financial services in high frequency which confirms the importance of analyzing the factors influencing consumers' acceptance to DFS for successful implementation of such services in Egypt. 
Table I: Respondent's profile

\begin{tabular}{|c|c|c|c|}
\hline \multicolumn{2}{|c|}{ Demographic Variable and category } & Frequency & Percentage \\
\hline \multirow{2}{*}{ Gender } & Male & 69 & $4 \mathrm{I} .3$ \\
\hline & Female & 98 & 58.7 \\
\hline \multirow{5}{*}{ Age } & $18-25$ & 47 & 28.3 \\
\hline & $26-35$ & 64 & 38.4 \\
\hline & $36-45$ & 44 & $26 . \mathrm{I}$ \\
\hline & $46-55$ & 9 & 5.1 \\
\hline & 56 or greater & 3 & 2.1 \\
\hline \multirow{3}{*}{ Employ Status } & Employed & I3I & 78.3 \\
\hline & Self-Employed & $\mathrm{I} 2$ & 7.2 \\
\hline & Student & 24 & 14.5 \\
\hline \multirow{3}{*}{ Education } & University Student & 24 & 14.5 \\
\hline & Bachelor & 82 & $49 \cdot 3$ \\
\hline & Master or More & 6I & 36.2 \\
\hline \multirow{4}{*}{ Income } & Less than 3000 & I8 & 10.9 \\
\hline & $3000-6000$ & 55 & 32.6 \\
\hline & $6000-10,000$ & 42 & 25.4 \\
\hline & More than Io,ooo & 52 & $3 \mathrm{I} .2$ \\
\hline \multirow{3}{*}{$\begin{array}{l}\text { Digital Financial } \\
\text { Service Usage }\end{array}$} & Usually & 102 & 60.9 \\
\hline & Occasionally & 60 & 36.2 \\
\hline & Never & 5 & 2.9 \\
\hline
\end{tabular}

\section{3-2 INSTR UMENT MEASURES}

In designing the questionnaire, detailed review was made on relevant literature concerning consumers' intention to adopt new digital financial services. This paper made all the appropriate adjustments according to the features of digital financial services studied in this paper. The questionnaire consists of 33 item -27 items related to consumer acceptance behaviour and 6 demographic items related to respondent profile - represent the measurement scale for the study. The questionnaire was then tested in a pilot study of 30 respondents to ensure the validity and reliability of the measurement variables and to find out if the questionnaire is time consistent or not. Based on the respondent feedback the questionnaire was modified by omitting few questions to ensure its accuracy and appropriateness. The measurement scale consists of eight constructs (latent variables) where each variable composed of two to five measurement variables. All multiple items (questions) were expressed by five - point Likert scale from I (strongly disagree) to 5 (strongly agree). The measurement variables are shown in table 2 . 
Furthermore, for data analysis structural equation model (SEM) method was employed. SEM technique is widely used in behaviour sciences in general and specifically in analyzing consumers' behaviour toward adopting new technologies. This method is used to test the casual relationships between dependent variable (intention to use) and the independent variables (perceived usefulness, perceived ease of use, trust, attitude, government support, perceived risk, and perceived cost). Partial least square (PLS) is a parameter estimation method of SEM. Therefore, this paper used PLS - SEM method where measurement model is analysed to test the validity and reliability of the instruments and then hypothesis was testing using SEM (paraphrase). Thus, the data analysis was processed using SmartPLS 3.0 software.

Table 2: Measurement Instruments

\begin{tabular}{|c|c|c|}
\hline $\begin{array}{c}\text { Latent } \\
\text { Variables }\end{array}$ & Measurement Items & Sources \\
\hline \multirow{5}{*}{$\begin{array}{l}\text { Perceived } \\
\text { Usefulness } \\
\quad(\mathrm{PU})\end{array}$} & Using mobile banking can meet my service needs & \multirow{5}{*}{$\begin{array}{l}\text { Rahi et al., (2018), Hu et al., } \\
\text { (2019) and Cheng et al., (2006) }\end{array}$} \\
\hline & $\begin{array}{l}\text { Internet banking gives reliable information before } \\
\text { transactions }\end{array}$ & \\
\hline & Using digital finance services improve efficiency. & \\
\hline & $\begin{array}{l}\text { Using digital financial applications (mobile } \\
\text { banking, MyFawry, 7awshly, etc.) save time }\end{array}$ & \\
\hline & Overall, digital financial services are useful. & \\
\hline \multirow{3}{*}{$\begin{array}{l}\text { Perceived Ease } \\
\text { of Use (PEU) }\end{array}$} & It is easy to learn how to use mobile banking & \multirow{3}{*}{$\begin{array}{l}\text { Wang et al., (2014), Davis (1989), } \\
\text { and Adams et al., (1992) }\end{array}$} \\
\hline & $\begin{array}{l}\text { It is easy to make online payments through online } \\
\text { payment gateways }\end{array}$ & \\
\hline & $\begin{array}{l}\text { It is easy to interact with digital financial } \\
\text { applications }\end{array}$ & \\
\hline \multirow{2}{*}{$\begin{array}{l}\text { Attitude } \\
\text { (ATT) }\end{array}$} & I believe using digital finance is necessary. & \multirow{2}{*}{$\begin{array}{l}\text { Grabner at al (2008) and Hu et } \\
\text { al., (2019) }\end{array}$} \\
\hline & I am interested in digital financial services & \\
\hline \multirow{2}{*}{$\begin{array}{l}\text { Perceived Risk } \\
\qquad(\mathrm{PR})\end{array}$} & $\begin{array}{l}\text { I feel safe to pay money through mobile banking } \\
\text { applications }\end{array}$ & \multirow{2}{*}{$\begin{array}{l}\text { Ndubisi \& Sinti (2006), and } \\
\text { Grabner at al., (2008) }\end{array}$} \\
\hline & $\begin{array}{l}\text { I believe that personal privacy will be disclosed by } \\
\text { using online payments gateways }\end{array}$ & \\
\hline \multirow{2}{*}{$\begin{array}{l}\text { Perceived Cost } \\
\qquad(\mathrm{PC})\end{array}$} & Internet banking imply lower transaction cost & \multirow[b]{2}{*}{ Alarmo \& Latif (2019) } \\
\hline & $\begin{array}{l}\text { Digital financial application has lower cost than } \\
\text { other traditional channels }\end{array}$ & \\
\hline \multirow{2}{*}{$\begin{array}{l}\text { Government } \\
\text { Support (GS) }\end{array}$} & $\begin{array}{l}\text { I believe the government has introduced favorable } \\
\text { legislation and regulations for digital financial } \\
\text { services. }\end{array}$ & \multirow{2}{*}{$\begin{array}{l}\text { Teo et al. (1997), Tan \& } \\
\text { Teo (200o), and Marakarkandy } \\
\text { et al., (2016) }\end{array}$} \\
\hline & $\begin{array}{l}\text { I believe that the government improve digital } \\
\text { financial services by setting all kind of } \\
\text { infrastructure such as telecom network }\end{array}$ & \\
\hline
\end{tabular}




\begin{tabular}{|c|c|c|}
\hline & $\begin{array}{l}\text { I believe government support increase consumers' } \\
\text { trust in using digital financial services (search ref) }\end{array}$ & \\
\hline \multirow[b]{2}{*}{ Trust (TRU) } & I believe internet banking is trustable & \multirow{2}{*}{$\begin{array}{l}\text { Chong et al., (2010), Sanchez - } \\
\text { Torrez et al., (2018), and Hu et } \\
\text { al., (2019) }\end{array}$} \\
\hline & $\begin{array}{l}\text { I believe online payment gateways keep my } \\
\text { information safe }\end{array}$ & \\
\hline \multirow{3}{*}{$\begin{array}{l}\text { Intention } \\
\text { (INT) }\end{array}$} & $\begin{array}{l}\text { I intent to use online payment gateways in the } \\
\text { future }\end{array}$ & \multirow{3}{*}{$\begin{array}{l}\text { Marakarkandy et al., (2016), Hu } \\
\text { et al., (2019), and Patel et al., } \\
\text { (2018) }\end{array}$} \\
\hline & I will like to use mobile banking applications & \\
\hline & $\begin{array}{l}\text { If I have used digital financial applications, I am } \\
\text { willing to continue using it. }\end{array}$ & \\
\hline
\end{tabular}

\section{4- RESULTS}

\section{4-i Measurement Model Assessment}

This study follows the two-step approach recommended by Hair et al. (2006) and Schumacker and Lomax (2004). First, we test the validation of the measurement model, then the structural model was assessed.

\section{4-I-I RELIABILITY AND VALIDITY OF MEASUREMENT INSTR UMENTS}

Assessment of measurement model require testing for reliability, convergent validity, and discriminant validity. Reliability measures the internal consistency of the measurement items based on three criteria: Individual item reliability, Composite Reliability (CR) and Average Variance Extracted (AVE) (Hair et al., 20IO). Individual measurement items (variables) are reliable if the outer loadings are greater than 0.7 where the variable is considered valid in this case. Furthermore, internal consistency of the measurement model is tested through composite reliability and Cronbach's alpha. For more satisfactory results, values between 0.7 and 0.9 are acceptable (Nunally and Bemstein, 1994; Hair et al., 20I0; and Ursachi; 20I5). Although Cronbach's alpha was traditionally used to test for constructs measures' consistency, composite reliability provides a more appropriate measure of internal consistency reliability when using PLS - SEM as it prioritizes variables based on their individual reliability (Hair et al., 20I4). Average variance extracted (AVE) greater than 0.5 is preferred (Fornell \& Larcker, 198I and Byrne, 200I), this ratio implies that all reflective indicators are explaining the underlying latent construct. As shown in table 3, outer loadings are all greater than o.7, Composite Reliability and Cronbach's alpha are greater than 0.7 and AVE is greater than 0.5. These results indicate that the variables are reliable, valid - convergent validity is ensured - and the model is consistent. 
Table 3: Reliability and Validity Measures

\begin{tabular}{|c|c|c|c|c|c|}
\hline Constructs & Indicator & $\begin{array}{c}\text { Factor } \\
\text { Loadings }\end{array}$ & AVE & CR & $\begin{array}{c}\text { Cronbach's } \\
\text { Alpha }\end{array}$ \\
\hline \multirow{5}{*}{ PU } & PUI & 0.709 & \multirow{5}{*}{$0.6 \mathrm{II}$} & \multirow{5}{*}{0.885} & \multirow{5}{*}{0.837} \\
\hline & $\mathrm{PU}_{2}$ & 0.734 & & & \\
\hline & $\mathrm{PU}_{3}$ & 0.842 & & & \\
\hline & $\mathrm{PU}_{4}$ & 0.803 & & & \\
\hline & $\mathrm{PU}_{5}$ & 0.901 & & & \\
\hline \multirow{3}{*}{ PEU } & PEUI & 0.839 & \multirow{3}{*}{0.667} & \multirow{3}{*}{0.857} & \multirow{3}{*}{0.752} \\
\hline & $\mathrm{PEU}_{2}$ & $0.76 \mathrm{I}$ & & & \\
\hline & $\mathrm{PEU}_{3}$ & 0.847 & & & \\
\hline \multirow{2}{*}{ PR } & PRI & 0.946 & \multirow{2}{*}{0.619} & \multirow{2}{*}{0.755} & \multirow{2}{*}{$0.72 \mathrm{I}$} \\
\hline & $\mathrm{PR}_{2}$ & 0.732 & & & \\
\hline \multirow{2}{*}{ PC } & PCI & $0.9 \mathrm{II}$ & \multirow{2}{*}{0.724} & \multirow{2}{*}{0.839} & \multirow{2}{*}{$0.7 \mathrm{OI}$} \\
\hline & $\mathrm{PC}_{2}$ & 0.786 & & & \\
\hline \multirow{3}{*}{ GS } & $\mathrm{GS}_{\mathrm{I}}$ & $0.83 \mathrm{I}$ & \multirow{3}{*}{$0.7 \mathrm{II}$} & \multirow{3}{*}{$0.88 \mathrm{o}$} & \multirow{3}{*}{0.896} \\
\hline & $\mathrm{GS}_{2}$ & 0.890 & & & \\
\hline & $\mathrm{GS}_{3}$ & 0.807 & & & \\
\hline \multirow{2}{*}{ TRU } & TRUI & 0.959 & \multirow{2}{*}{0.919} & \multirow{2}{*}{0.958} & \multirow{2}{*}{0.912} \\
\hline & $\mathrm{TRU}_{2}$ & 0.958 & & & \\
\hline \multirow{2}{*}{ ATT } & $\mathrm{ATTI}_{\mathrm{I}}$ & 0.903 & \multirow{2}{*}{0.787} & \multirow{2}{*}{$0.88 \mathrm{I}$} & \multirow{2}{*}{0.830} \\
\hline & $\mathrm{ATT}_{\mathrm{I}}$ & 0.870 & & & \\
\hline \multirow{3}{*}{ INT } & INTI $_{I}$ & 0.826 & \multirow{3}{*}{0.719} & \multirow{3}{*}{0.884} & \multirow{3}{*}{0.804} \\
\hline & $\mathrm{INT}_{2}$ & 0.842 & & & \\
\hline & $\mathrm{INT}_{3}$ & 0.874 & & & \\
\hline
\end{tabular}

Discriminant validity reflects the extent to which measurement items of each variable is not correlated and hence the measurement of each variable measures what it intends to measure (Hair et al., 2014). The first criteria used is FornellLarcker criterion which states that the square root of AVE must be greater than the correlation of the reflective construct with all other constructs (Fornell \& Larcker, 1981; Chin, 2010; and Chine, 1998). The second criterion is cross-loadings which states that the loadings of all indicators should be higher than its loadings on all other latent variables. As shown in table 4, the square root of AVE is greater than the correlation coefficients with each latent variable. The result below shows that the discriminant validity of each variable is satisfactory. 
Table 4: Discriminant validity of the constructs (Fornell \& Larcker criteria)

\begin{tabular}{|c|c|c|c|c|c|c|c|c|}
\hline & ATT & GS & INT & PC & PEU & PR & PU & $\begin{array}{c}\text { TR } \\
\text { U }\end{array}$ \\
\hline ATT & 0.887 & & & & & & & \\
\hline GS & 0.235 & 0.843 & & & & & & \\
\hline INT & 0.756 & 0.172 & 0.848 & & & & & \\
\hline PC & 0.315 & 0.194 & 0.190 & $0.85 \mathrm{I}$ & & & & \\
\hline PEU & 0.430 & 0.293 & 0.386 & 0.305 & 0.816 & & & \\
\hline PR & 0.421 & 0.191 & 0.472 & 0.288 & 0.336 & 0.787 & & \\
\hline PU & 0.699 & 0.405 & 0.589 & 0.448 & 0.594 & 0.521 & $0.78 \mathrm{I}$ & \\
\hline TRU & 0.212 & 0.474 & 0.249 & 0.236 & 0.316 & 0.508 & 0.448 & 0.959 \\
\hline
\end{tabular}

Recently, the heterotrait-monotrait ratio of correlations (HTMT) has become the primary criterion for assessing discriminant validity since it offers superior performance compared with the Fornell-Larcker criterion and the assessment of cross-loadings (Henseler et al. 20I5 and Hair et al., 2017). HTMT ratio below 0.9 is acceptable. As shown in table 5 , all variables have a critical value below 0.9. these results confirmed discriminant validity.

Table 5: Discriminant Validity (Heterotrait-Monotrait Ratio (HTMT)

\begin{tabular}{|c|c|c|c|c|c|c|c|c|}
\hline & ATT & GS & INT & PC & PEU & PR & PU & TRU \\
\hline ATT & & & & & & & & \\
\hline GS & 0.310 & & & & & & & \\
\hline IN & 0.879 & 0.216 & & & & & & \\
\hline PC & 0.447 & 0.239 & 0.266 & & & & & \\
\hline PEU & 0.563 & 0.389 & 0.507 & 0.425 & & & & \\
\hline PR & 0.614 & 0.340 & 0.596 & 0.487 & $\begin{array}{c}0.47 \\
9\end{array}$ & & & \\
\hline PU & 0.869 & 0.507 & 0.696 & 0.605 & $\begin{array}{c}0.74 \\
0\end{array}$ & 0.760 & & \\
\hline TRU & 0.265 & 0.555 & 0.292 & 0.293 & $0.38 \mathrm{I}$ & 0.736 & 0.530 & - \\
\hline
\end{tabular}

\section{4-2 Structural Model Assessment}

Once the reliability and validity of the measurement model is examined, the hypothesized relationships within the structural model must be evaluated. Since PLS - SEM does not have a unified goodness of fit test, the structural model assessment is based on its ability to predict the endogenous constructs using three 
criteria; Coefficient of determination $\left(\mathrm{R}^{2}\right)$, Cross Validated Redundancy $\left(\mathrm{Q}^{2}\right)$ and Effect Size ( $\left.\mathrm{F}^{2}\right)$ (Henseler and Sarstedt, 20I3; Hair et al; 20I8).

\section{4-2-I COEFFICIENT OF DETERMINATION $\left(R^{2}\right)$}

The coefficient of determination $\left(\mathrm{R}^{2}\right)$ is the most commonly used measures to evaluate the structural model. $\mathrm{R}^{2}$ examines the predictive power of the structural model. In other words, it examines the exogenous constructs combined effects on endogenous construct (Elliot \& Woodward, 2007; Hair et al., 2006; 2011). As a rough rule of thumb $\mathrm{R}^{2}$ values of $0.25,0.50$, and 0.75 represent weak, moderate, and substantial levels (Hair et al., 20II, 2017 and Henseler et al., 2009). However, in some disciplines such as consumer behaviour $\mathrm{R}^{2}$ value of 0.2 is considered high and thus acceptable (Hair et al.; 20II; 20I8). Similarly, Falk and Miller (1992) suggest that in social studies disciplines $\mathrm{R}^{2}$ values below o.I9 is unacceptable, while values range from 0.33 to 0.67 are considered moderate. As shown in table 7 , according to Hair et al., (20II, 20I8), all values of adjusted $\mathrm{R}^{2}$ are acceptable as it's above the minimum threshold of 0.20 and the model shows moderate predictive accuracy of 0.568 where $56.8 \%$ of the variation in consumer intention towards the use of digital financial services (endogenous construct) is explained by perceived usefulness, perceived ease of use, trust, government support, perceived risk, and perceived cost.

Table 6: $\mathrm{R}^{2}$ and adjusted $\mathrm{R}^{2}$

\begin{tabular}{|c|c|c|}
\hline Variable & $\mathrm{R}^{2}$ & Adjusted $\mathrm{R}^{2}$ \\
\hline Attitude & 0.516 & 0.493 \\
\hline Intention to use & $0.57 \mathrm{I}$ & 0.568 \\
\hline Perceived Usefulness & 0.353 & 0.348 \\
\hline Trust & 0.405 & 0.397 \\
\hline
\end{tabular}

\section{4-2-2 THE EFFECT SIZE $F^{2}$}

This statistic measures the extent through which each specified exogenous construct can strongly explain the variation in the endogenous constructs. Therefore, if the exogenous construct is important and has strong effect on the endogenous variable, its effect size $\mathrm{f}^{2}$ will be high. According to Cohen (1998) $\mathrm{f}^{2}$ values of 0.02 , 0.15 , and 0.35 have small, medium, and large effects respectively. 
Table 8 shows that the effect of attitude on intention to use is large with I.33O effect size.

Table 7: The Effect Size

\begin{tabular}{|c|c|}
\hline Construct's relation & $\mathrm{f}^{\mathbf{2}}$ \\
\hline ATT $\rightarrow$ INT & I.330 \\
\hline GS $\rightarrow$ ATT & 0.000 \\
\hline GS $\rightarrow$ TRU & 0.248 \\
\hline PC $\rightarrow$ ATT & $0.05 \mathrm{I}$ \\
\hline PEU $\rightarrow$ ATT & $0.00 \mathrm{I}$ \\
\hline PEU $\rightarrow$ PU & 0.545 \\
\hline PR $\rightarrow$ ATT & 0.026 \\
\hline PR $\rightarrow$ TRU & 0.305 \\
\hline PU $\rightarrow$ ATT & 0.433 \\
\hline TRU $\rightarrow$ ATT & 0.040 \\
\hline
\end{tabular}

\section{4-2-3 CROSS VALIDATED REDUNDANCY $\left(Q^{2}\right)$}

Cross validated redundancy $\left(\mathrm{Q}^{2}\right)$ is used to assess the structural model predictive relevance. This statistic is calculated by running the blindfolding procedures in Smart PLS for each endogenous construct. According to Chin (1998), if the value of $Q_{2}$ for an endogenous construct is greater than zero, this indicate that the exogenous construct has predictable power (Hier et al., 20II). Also, according to Henseler et al., (2009) values of 0.02, 0.15, and 0.35 have small, medium, and large predictive power. Table 9 shows that all $\mathrm{Q}^{2}$ values acceptable as it's above zero.

Table 8: Predictive Relevance Assessment

\begin{tabular}{|c|c|}
\hline Construct & $\mathrm{Q}^{2}$ \\
\hline ATT & 0.363 \\
\hline INT & 0.394 \\
\hline PU & 0.207 \\
\hline TRU & 0.364 \\
\hline
\end{tabular}

\section{4-3 Structural Equation Model \& Hypothesis Testing}

\section{4-3-I DIRECT RESULTS}

Since the assessment of the measurement model revealed satisfactory reliability, validity, and fit results, we proceed to the second step which is testing the structural Model (Hair et al., 1995). Structural Equation Model (SEM) is a regression technique that is widely used in consumer behavior disciplines that examine causal relationship among multiple sets of variables defined previously in the structural model (Bollen \& Long, 1993; Ooi \& Tan, 2016; and Hu et al., 2019). 
Bootstrapping procedure was used to examine the significance of the path coefficients in PLS - SEM (Hair et al. 2017). Running Bootstrapping procedure gives us path coefficients, $t$ - value, and $p$ value. In general, if $t>1.96$, the hypothesized test is significant at the $\mathrm{p}<0.05$ confidence level.

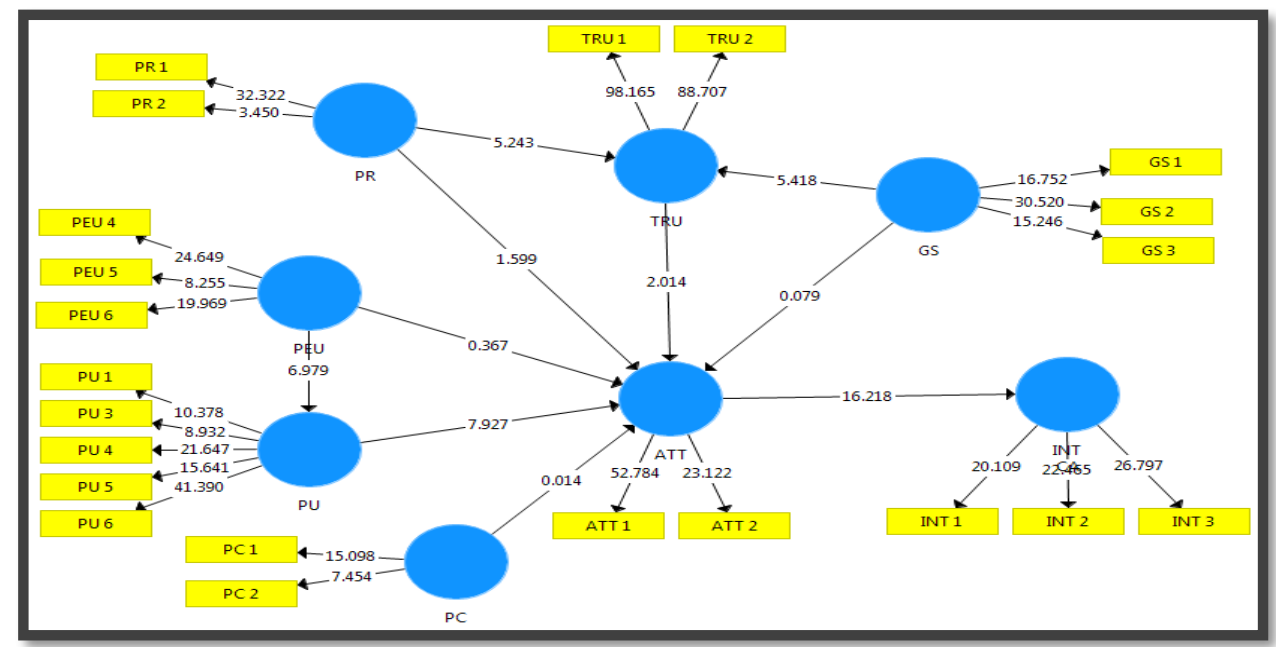

Figure 2: shows the PLS bootstrapping for the proposed model in this study

With respect to the hypotheses testing, six out the proposed hypothesis is accepted, while four are rejected. Table Io shows $\mathrm{t}$ - statistic, $\mathrm{p}$ value, and the path coefficients significance levels between constructs. The results indicate that perceived usefulness (PU) and trust (TRU) have positive significant impact on the consumer's attitude (ATT) towards the use of digital financial services (DFS) with $t$ - values of 7.927, and 2.014 respectively. Thus hypotheses $\mathrm{H}_{\mathrm{I}}$, and $\mathrm{H}_{5}$, while $\mathrm{H}_{6}$ were not supported. The results also confirmed the positive relation between consumers' attitude (ATT) and their intention (INT) to use mobile banking applications and other digital financial services (DFS), in other words, attitude has the most significant influence on consumers' intention to use DFS with t statistic of $\mathrm{I} 6 . \mathrm{I} 28$ and thus hypothesis $\mathrm{H}_{4}$ were supported.

\section{4-3-2 INDIRECT RESULTS}

On the other hand, government support (GS) and perceived risk (PR) with $t$ values of 5.418 and 5.243 have indirect effect on consumers' intention to use digital financial services through their effect on consumers' trust and thus TRU is said to play a significant intermediary role. Therefore, hypotheses $\mathrm{H}_{7}$ and $\mathrm{H}_{9}$ were also supported. Although Perceived ease of use (PEU) does not have a direct effect on 
consumers' attitude to use digital financial services, as initially hypothesized, it does influence their attitude indirectly through its positive significant impact on perceived usefulness (PU) with $\mathrm{t}$ - value of 6.979 and thus confirming $\mathrm{H}_{3}$ hypothesis.

However, government support (GS), perceived cost (PC), and perceived ease of use (PEU) had no significant impact on consumers' attitude where their $\mathrm{t}$ - values where less than $\mathrm{I} .96$ and thus hypotheses $\mathrm{H}_{2}, \mathrm{H}_{8}$, and $\mathrm{H}_{\text {Io }}$ were not supported.

Table 9: Significance testing results of the structural model path coefficients

\begin{tabular}{|c|c|c|c|c|c|c|c|}
\hline Hypothesis & $\begin{array}{c}\text { Construct's } \\
\text { Relationship }\end{array}$ & $\begin{array}{c}\text { Original } \\
\text { sample }\end{array}$ & $\begin{array}{c}\text { Sample } \\
\text { Mean }\end{array}$ & $\begin{array}{c}\text { Standard deviation } \\
\text { STDEV }\end{array}$ & T - statistic & P - value & Significance \\
\hline $\mathrm{H}_{1}$ & PU $\rightarrow$ ATT & 0.685 & 0.670 & 0.086 & 7.927 & 0.000 & Significant \\
\hline $\mathrm{H}_{2}$ & PEU $\rightarrow$ ATT & 0.029 & 0.041 & 0.080 & 0.367 & 0.714 & Not significant \\
\hline $\mathrm{H}_{3}$ & PEU $\rightarrow$ PU & 0.594 & 0.586 & 0.085 & 6.979 & 0.000 & Significant \\
\hline $\mathrm{H}_{4}$ & ATT $\rightarrow$ INT & 0.756 & 0.754 & 0.047 & 16.128 & 0.000 & Significant \\
\hline $\mathrm{H}_{5}$ & TRU $\rightarrow$ ATT & 0.181 & 0.194 & 0.090 & 2.014 & 0.045 & Significant \\
\hline $\mathrm{H}_{6}$ & PR $\rightarrow$ ATT & -0.144 & 0.146 & 0.094 & 1.528 & 0.127 & Not Significant \\
\hline $\mathrm{H}_{7}$ & PR $\rightarrow$ TRU & -0.434 & 0.422 & 0.083 & 5.243 & 0.000 & Significant \\
\hline $\mathrm{H}_{8}$ & GS $\rightarrow$ ATT & 0.007 & 0.020 & 0.088 & 0.097 & 0.937 & Not significant \\
\hline $\mathrm{H}_{9}$ & GS $\rightarrow$ TRU & 0.391 & 0.402 & 0.072 & 5.418 & 0.000 & Significant \\
\hline $\mathrm{H}_{10}$ & PC $\rightarrow$ ATT & -0.001 & 0.012 & 0.083 & 0.014 & 0.989 & Not significant \\
\hline
\end{tabular}

\section{5- DISCUSSION}

The main purpose of this paper is to examine the key factors that influence consumers' acceptance of using digital financial applications in Egypt. In other words, it analyzes their behavioural intention to use mobile banking applications and other online payment gateways. Concerning perceived usefulness and ease of use, core TAM constructs, the results revealed that perceived usefulness (PU) is one of the key influencing factors compared to ease of use (PEU) which is proved to have no influence. The result is consistent with prior studies applying TAM/ extended TAM model in consumer behaviour discipline (Chong et al., 2oIO; Chatzoglou et al., 20ı0; Celik, 2008; Cheng et al., 2006; Guriting and Ndubisi, 2006). Few scholars attribute the insignificance of perceived ease of use to users' experience in using new information technologies where more experienced internet users can easily learn how to use new technologies and thus ease of use does not affect consumers' intention in using DFS (Venkatesh et al.,20oo and Maditinos et al., 2013). Other scholars found that in the early stage of digitalization users are not familiar with the use of digital financial services (Davis et al., I998; $\mathrm{Hu}$ et al., 2019). Therefore, countries like Egypt, with digital financial inclusion 
index of 0.3I (Ayman and Ali, 202I), the insignificance of perceived ease of use reflect the fact that users still meet their financial needs in the traditional way because they are either unfamiliar with digital financial applications or lack the access to such digital financial services.

The results also revealed that perceived ease of use has indirect effect on consumer's intention to use DFS through its positive effect on perceived usefulness which is consistent with previous studies (Raleting \& Neil, 2oII; and Zarmpou et al., 20I2; Lim et al., 2020). This result indicates that if the application is user - friendly and consumers can easily learn how to use it, the usefulness of using digital financial applications will increase and thus consumers will be more likely to adopt such technologies. Hence, it can be concluded that consumers' decision to use DFS is based mainly on the perceived benefits - such as saving time, saving efforts, more effectiveness, and easier transactions - they receive from using such services compared to traditional financial services.

Regarding government support (GS), the results were surprising where although GS has significant impact on consumers' trust, it has no impact on their usage intention. This result is not consistent with the findings of Burn, 1995, Tan and Teo (2000), Jaruwachirathanakul and Fink (2005), and Chong et al., (2010). In developing countries, governments are key player in Information and Communication Technology (ICT) sector through their huge investments and thus it was expected to find a significant impact of GS on consumer intention to use DFS. In other words, users of DFS in Egypt believe that government support for DFS has no influence on their intention to use online banking and payment gateways. However, the results came in line with the results of Susanto et al., 2013, Sanchez - Torres, 2017 and Marakarkandy and Dasgupta; 2016). On the other hand, the results revealed that Government support to FinTech firms, internet banking and other digital financial applications through promoting laws, rules and regulations has significantly influence user trust in using DFS (Tan and Teo 2000; susanto et al., 2013; Chong et al. 20IO; and Marakarkandy and Dasgupta; 2016). A plausible explanation to why GS is enough to influence consumer trust but not sufficient to affect their intention to use DFS is that Egyptian citizens might not be aware of government role in supporting digital financial services over the last years. 
The findings also revealed that perceived cost has insignificant impact on consumer intention to use internet banking and other digital financial services. The results are in line with previous studies which found that financial cost has no impact on consumers' intention to use online financial services (Koksal, 2016; Koeing et al., 2010; and Gerrard and Cunningham, 2003). The cost of using internet in Egypt is very low compared to other countries such as Tunisia, Jordan, and Oman and coherent with average income earned, besides Egypt has the cheapest mobile internet packages compared to other Arab countries (ITU, 202I). In addition, using internet banking has no additional cost while other online payment gateways such as MyFawry charge very small fees when using the application to make any online payment. Therefore, perceived cost has no effect on consumers' intention to use DFS.

The results also found that perceived risk has indirect effect on consumers' intention to use digital financial services through its negative effect on trust. In other words, consumers' perceived risk of digital financial services is crucial factor in determining the level of trust in such services. If consumers trust these applications to keep their personal and financial information safe from any hacking or theft, there perceived risk will decrease and thus they will perform all their financial transactions online. The result is consistent with previous studies (Jarvenpaa et al., 2000; Yousafzai, 2005; Kesharwani and Bisht, 20I2; Pikkarainen et al., 2004; and Lee et al., 2007; Marakarkandy and Dasgupta; 2016)

Finally, trust is found to play an important role in adopting digital financial application in Egypt through its positive significant impact on consumers' attitude towards the use DFS and thus TRU is a crucial factor to the usage of DFS in Egypt. This result was supported by previous studies ( $\mathrm{Al}-\mathrm{Ajam}$ and $\mathrm{Md}$ Nor, 2013; Chong et al., 20I0; Hu et al., 2019) who found that if consumers are not certain that their financial information are secured, they will prefer to perform all their financial transactions face to face rather than online to protect their privacy.

\section{6- ACADEMIC AND MANAGERIAL IMPLICATIONS}

\section{6-i ACADEmic Implications}

The findings of the current study provide an important implication as it addressed the factors influencing the adoption of different digital financial services in Egypt, from consumer behaviour. Thus, it is advance knowledge in this the area of digital 
financial services which have much wider scope than internet banking. Moreover, the current study contributes to the literature by being the first to identify the factors influencing consumer acceptance to use not only to internet banking, but all digital financial services delivered in Egypt. Furthermore, this study shed light on the most significant variables that affect consumer intention to use new technologies in Egypt. Additionally, it develops a model that test consumer's attitude towards the adoption of digital financial services in the in Egypt context. Accordingly, the study contributes to a better knowledge in the field digital financial services and financial inclusion.

\section{6-2 Managerial Implications}

Digital finance is still in its early stage in Egypt and so consumers' feel uncertain about performing any online financial transactions. Consumers either have no awareness of the benefits of DFS, lack trust in service providers to protect their financial information, or do not know how to use these services. Therefore, based on our study results, bank managers and other digital financial service providers should focus on the following:

First, internet banking interface should be user - friendly to make it easier for customers to perform all their financial transaction smoothly without asking for help. Also, all necessary information should be available in both English and Arabic Languages.

Secondly, switching to cashless society through digitalizing all government payments will increase the level of trust.

Third, building secure firewalls and using encryption and authentication methods is a must to decrease all potential risks and increase consumers' trust.

Fourth, increasing the level of awareness on the benefits of using digital platforms to perform all needed financial transactions online through marketing and advertising strategies will enhance consumers' perception and thus have a positive attitude to adopt DFS.

Finally, in summary FinTech firms and bank' managers should invest in the factors that encourage more consumers to perform their financial transactions online. 


\section{7- STUDY LIMITATIONS AND FUTURE RESEARCH}

This study has some limitations that should be considered for future research. First, although the sample size is considered adequate, however, the sampling method produced sample that is not representative for the entire population, as the sample consists of digital finance users only which affect finding generalizations. Second, the study selects seven constructs to analyze Egyptian consumers' intention to adopt different digital financial services, however, other variables should be included. Therefore, more variables such as perceived benefits computer self-efficacy should be examined especially in developing countries where digital literacy is considered a strong barrier for digital finance usage. These limitations pave the way toward more future research.

\section{8- CONCLUSION}

The main objective of this paper is to the identify key factors influencing consumers' intention to use digital financial services (DFS) in Egypt. Although few studies took the attempt to identify the factors influencing consumers' behaviour to use internet banking, there is no study did identify the factors that influence the adoption of all digital finance in Egypt. This study fills in this gap. We use the extended TAM model to identify the factors influencing consumers' intention to use digital financial applications in Egypt. The factors examined are perceived usefulness (PU), Perceived ease of use (PEU), perceived risk (PR), perceived cost (PC), government support (GS) and Trust (TRU).

The results revealed that perceived usefulness (PU) and trust (TRU) have positive significant impact on consumers' intention (INT) for the adoption of digital financial services DFS. On the other hand, perceived ease of use (PEU), perceived Risk (PR), and Perceived cost (PC) are proved to have insignificant impact on consumers' intention to use DFS. Furthermore, regarding government support (GS), the results were surprising where we found no impact on consumers' usage intention. However, the results also revealed that government support (GS) and perceived risk (PR) have indirect effect on consumer's intention to use digital financial services through their effect on consumers' trust and thus TRU is said to play a significant intermediary role. Therefore, consumers' use digital financial services if using it is seen useful for them and if they trust the service provider. Then, they pay attention to government support and potential risks which will 
affect their behavioral attitude. Thus, trust and risks are identified in our study as key barriers for DFS adoption in Egypt, while cost of using internet banking or other online payment gateway is not considered a barrier that affect consumers' intentional behavior to use DFS.

\section{REFERENCES}

Abd Ghani, M.; Rahi, S.; Yasin, N. M., \& Alnaser, F. M. (2017). Adoption of internet banking: extending the role of technology acceptance model (TAM) with e-customer service and customer satisfaction. World Applied Sciences Journal, 35(9), 1918-1929.

Aboelmaged, M., \& Gebba, T. R. (2013). Mobile banking adoption: An examination of technology acceptance model and theory of planned behavior. International Journal of Business Research and Development, $2(\mathrm{I})$.

AbuShanab, E., \& Pearson, J. M. (2007). Internet banking in Jordan: The unified theory of acceptance and use of technology (UTAUT) perspective. Journal of Systems and information Technology.

Adams, D. A.; Nelson, R. R., \& Todd, P. A. (1992). Perceived usefulness, ease of use, and usage of information technology: A replication. MIS quarterly, 227-247.

Akturan, U., \& Tezcan, N. (2OI2). Mobile banking adoption of the youth market: Perceptions and intentions. Marketing Intelligence ES Planning.

Al-Ajam, A. S., \& Nor, K. M. (2013). Internet banking adoption: integrating technology acceptance model and trust. European Journal of Business and Management, 5(3), 207-215.

Al-Ajam, A. S., \& Nor, K. M. (2015). Challenges of adoption of internet banking service in Yemen. International journal of bank marketing.

Al-Ghaith, W.; Sanzogni, L., \& Sandhu, K. (2010). Factors influencing the adoption and usage of online services in Saudi Arabia. The Electronic Journal of Information Systems in Developing Countries, 40(I), I-32. 
Al-Somali, S. A.; Gholami, R., \& Clegg, B. (2009). An investigation into the acceptance of online banking in Saudi Arabia. Technovation, 29(2), I30I4I.

Anandarajan, M.; Igbaria, M. and Anakwe, U.P. (2000). Technology acceptance in the banking industry, a perspective from a less developed country, Information Technology and People, I3 (4), 298-3ı2.

Bansal, S. K.; Bansal, A., \& Blake, M. B. (2oro, December). Trust-based dynamic web service composition using social network analysis. In 2010 IEEE International Workshop on: Business Applications of Social Network Analysis $(B A S N A)(\mathrm{I}-8)$. IEEE.

Bauer, R. A. (1960). Consumer Behavior as Risk Taking. Risk Taking and Information Handling in Consumer Behavior, Boston University Press, Boston. MA, 23-33

Bebli, R. S. (2012). The Impact of internet banking service quality on customer satisfaction in the banking sector of Ghana.

Beck, T.; Demirguc-Kunt, A. and Peria, M.S.M. (2007). Reaching out: access to and use of banking services across countries, Journal of Financial Economics, 85 (I), 234-266.

Black, N.; Lockett, A.; Winklhofer, H. and Ennew, C. (20oI). The adoption of internet financial services: a qualitative study, International Journal of Retail ES Distribution Management, 29 (8), 390-8.

Bollen, K. A., \& Long, J. S. (1993). Testing structural equation models (154). Sage.

Burgess, R., \& Pande, R. (2005). Do rural banks matter? Evidence from the Indian social banking experiment. American Economic Review, 95(3), 780-795.

Byrne, B. M. (200I). Structural equation modeling with AMOS, EQS, and LISREL: Comparative approaches to testing for the factorial validity of a measuring instrument. International journal of testing, I(I), 55-86.

Celik, H. (2008). What determines Turkish customers' acceptance of internet banking? International journal of bank marketing. 
Chan, S.C. and Lu, M.T. (2004). Understanding internet banking adoption and usage behavior: a Hong Kong perspective, Journal of Global Information Management, I2 (3), 2I-43.

Chatzoglou, P. D.; Diamantidis, A. D.; Vraimaki, E.; Polychrou, E., \& Chatzitheodorou, K. (2010). Banking productivity: an overview of the Greek banking system. Managerial Finance, 36(I2), I007-IO27.

Chellappa, R. K., \& Pavlou, P. A. (2002). Perceived information security, financial liability and consumer trust in electronic commerce transactions. Logistics Information Management.

Chen, J. S., \& Ching, R. K. (2002). A proposed framework for transitioning to an e-business model. Quarterly Journal of electronic commerce, 3(4), 375-389.

Chen, L., Gillenson, M. and Sherrell, D. (2002). "Enticing online consumers: an extended.

Cheng, T. C.; Lam, D. Y., \& Yeung, A. C. (2006). Adoption of internet banking: An empirical study in Hong Kong. Decision Support Systems, 42(3), I558-I572.

Chiemeke, S. C.; Evwiekpaefe, A. E., \& Chete, F. O. (2006). The adoption of Internet banking in Nigeria: An empirical investigation. Journal of Internet banking and Commerce, II(3), I-IO.

Chin, W. W. (1998). Commentary: Issues and opinion on structural equation modeling.

Chong, A. Y. L.; Ooi, K. B.; Lin, B., \& Tan, B. I. (2010). Online banking adoption: an empirical analysis. International Journal of bank marketing.

Chong, A.Y. and Ooi, K.B. (2008). Adoption of interorganizational system standards in supply chains: an empirical analysis of RosettaNet standards, Industrial Management \& Data Systems, Io8 (4), 529-47.

Cohen, J. (1992). Statistical power analysis. Current directions in psychological science, I(3), 98-IOI.

Cronbach, L. J., \& Meehl, P. E. (1955). Construct validity in psychological tests. Psychological bulletin, 52(4), 28I. 
Cruz, P.; Neto, L. B. F.; Muñoz-Gallego, P., \& Laukkanen, T. (20Io). Mobile banking rollout in emerging markets:evidence from Brazil. International Journal of bank marketing.

Dass, R., \& Pal, S. (20II). A meta analysis on adoption of mobile financial services. Indian Institute of Management Abmedabad, 2(I), I-26.

Davis, F. D. (1989). Perceived usefulness, perceived ease of use, and user acceptance of information technology. MIS quarterly, 319-340.

Demirguc-Kunt, A.; Klapper, L.; Singer, D., \& Ansar, S. (2018). The Global Findex Database 2017: Measuring financial inclusion and the fintech revolution. World Bank Publications.

Ekin, S. and Polaoglu, V.N. (20oI). An empirical investigation of the Turkish consumer's acceptance of internet banking services, International Journal of Bank Marketing, 19 (4), 156-165.

El-Kasheir, D.; Ashour, A. S., \& Yacout, O. M. (2009). Factors affecting continued usage of internet banking among Egyptian customers. Communications of the IBIMA, $9,252-263$.

El Aziz, R. A.; El Badrawy, R., \& Hussien, M. I. (20I4). ᄀATM, Internet Banking and Mobile Banking Services in a Digital Environment: The Egyptian Banking Industry. International Journal of Computer Applications, $90(8)$.

Elliot, A. C., \& Woodward, W. A. (2007). Analysis of categorical data. Statistical Analysis Quick Reference Guidebook, II4-I3I.

Ennew, C., \& Sekhon, H. (2007). Measuring trust in financial services: The trust index. Consumer Policy Review, ${ }_{7}(2), 62$.

Falk, R. F., \& Miller, N. B. (1992). A primer for soft modeling. University of Akron Press.

Fishbein, M., \& Ajzen, I. (1975). Belief, Attitude, Intention, and Behaviour. An Introduction to Theory and Research. Reading, MA: Addison-Wesley Publishing.

Fornell, C., \& Larcker, D. F. (198I). Structural equation models with unobservable variables and measurement error: Algebra and statistics. 
Friedman, B.; Khan Jr, P. H., \& Howe, D. C. (2000). Trust online. Communications of the ACM, 43(I2), 34-40.

George, J. F. (2002). Influences on the intent to make Internet purchases. Internet Research.

Gerrard, P.; Cunningham, J. B., \& Devlin, J. F. (2006). Why consumers are not using internet banking: a qualitative study. Journal of services Marketing.

Goles, T.; Lee, S. J.; Rao, S.V. and Warren, J. (2009). Trust violations in electronic commerce: customer concerns and reactions, Journal of Computer Information Systems, 49 (I), I-9.

Gomber, P.; Koch, J. A., \& Siering, M. (2017). Digital Finance and FinTech: current research and future research directions. Journal of Business Economics, 87(5), 537-580.

Grabner-Kräuter, S., \& Faullant, R. (2008). Consumer acceptance of internet banking: the influence of internet trust. International Journal of bank marketing.

Guriting, P., \& Ndubisi, N. O. (2006). Borneo online banking: evaluating customer perceptions and behavioural intention. Management research news.

Hai, L. C., \& Alam Kazmi, S. H. (20I5). Dynamic support of government in online shopping. Asian social science, II(22).

Hult, G. T. M., Hair Jr, J. F.; Proksch, D.; Sarstedt, M.; Pinkwart, A., \& Ringle, C. M. (2018). Addressing endogeneity in international marketing applications of partial least squares structural equation modeling. Journal of International Marketing, 26(3), I-2I.

Hair, J. F.; Black, W. C.; Babin, B. J., \& Anderson, R. E. (20Io). Multivariate data analysis (7th ed.). Englewood Cliffs: Prentice Hall

Hair, J. F.; Ringle, C. M., \& Sarstedt, M. (20II). PLS-SEM: Indeed a silver bullet. Journal of Marketing Theory and Practice, I9(2), I39-I5I. 
Hair, J. F.; Sarstedt, M.; Ringle, C.M. \& Mena, J.A. (20I2). An assessment of the use of partial least squares structural equation modeling in marketing research. Journal of the Academy of Marketing Science, 40(3), 4I4-433

Hair Jr, J. F.; Sarstedt, M.; Hopkins, L., \& Kuppelwieser, V. G. (20I4). Partial least squares structural equation modeling (PLS-SEM): An emerging tool in business research. European business review.

Hair Jr, J. F.; Hult, G. T. M.; Ringle, C. M., \& Sarstedt, M. (2017). A primer on partial least squares structural equation modeling (PLS-SEM). Sage publications.

Hanafizadeh, P.; Behboudi, M.; Koshksaray, A. A., \& Tabar, M. J. S. (20I4). Mobile-banking adoption by Iranian bank clients. Telematics and informatics, 3I(I), 62-78.

Heijden, H. (2003). Factors influencing the usage of websites: the case of a generic portal in The

Heng, T. M., \& Low, L. (1993). The intelligent city: Singapore achieving the next lap: Practitoners forum. Technology Analysis Ef Strategic Management, $5(2)$, 187-202.

Henseler, J., \& Sarstedt, M. (2013). Goodness-of-fit indices for partial least squares path modeling. Computational statistics, 28(2), 565-580.

Henseler, J.; Hubona, G., \& Ray, P. A. (2016). Using PLS path modeling in new technology research: updated guidelines. Industrial management \& data systems.

Henseler, J.; Ringle, C. M., \& Sinkovics, R. R. (2009). The use of partial least squares path modeling in international marketing. In New challenges to international marketing. Emerald Group Publishing Limited.

Hu, Z.; Ding, S.; Li, S.; Chen, L., \& Yang, S. (2019). Adoption intention of fintech services for bank users: An empirical examination with an extended technology acceptance model. Symmetry, II(3), 340.

Huang, Y., \& Zhang, Y. (2020). Financial inclusion and urban-rural income inequality: Long-run and short-run relationships. Emerging Markets Finance and Trade, 56(2), 457-47I. 
Ismael, D. \& Ali, S. (202I, February). Measuring Digital and Traditional Financial Inclusion in Egypt: A New Index. $3^{\text {rd }}$ International Conference on Management, Economics and Finance.

Jaruwachirathanakul, B. and Fink, D. (2005). Internet banking adoption strategies for development country: the case of Thailand, Internet Research, 15 (3), 295-3II

Jarvenpaa, S. L.; Tractinsky, N., \& Vitale, M. (2000). Consumer trust in an Internet store. Information technology and management, I(I), 45-7I.

Jussawalla, M.; Toh, M. H., \& Low, L. (1992). Singapore: An Intelligent CityState. Asian Journal of Communication, 2(3), I5-29

Kamel, S. \& Hassan, A. (2003). Assessing the Introduction of Electronic Banking in Egypt Using the Technology Acceptance Model. Annals of Cases on Information Technology, 5, I-26.

Kesharwani, A., \& Bisht, S. S. (2012). The impact of trust and perceived risk on internet banking adoption in India: An extension of technology acceptance model. International journal of bank marketing.

Khedmatgozar, H. R., \& Shahnazi, A. (20I8). The role of dimensions of perceived risk in adoption of corporate internet banking by customers in Iran. Electronic Commerce Research, I8(2), 389-4I2.

Kim, D. J.; Ferrin, D.L. and Rao, H.R. (2008). A trust-based consumer decisionmaking model in electronic commerce: the role of trust, perceived risk, and their antecedents, Decision Support Systems, 44 (2), 544-564.

Kleijnen, M.; Wetzels, M., \& De Ruyter, K. (2004). Consumer acceptance of wireless finance. Journal of financial services marketing, 8(3), 206-217.

Koenig-Lewis, N.; Palmer, A. \& Moll, A. (20I0). Predicting young consumers' take up of mobile banking services. International journal of bank marketing, 28 (5), 410-432

Koksal, M. H. (2016). The intentions of Lebanese consumers to adopt mobile banking. International Journal of Bank Marketing, 34(3), 327-346 
Kumar Sharma, S., \& Madhumohan Govindaluri, S. (2014). Internet banking adoption in India: structural equation modeling approach. Journal of Indian Business Research, 6(2), 155-169

Lai, P. C. (2016). Design and Security impact on consumers' intention to use single platform E-payment. 22(I), III-I22. https://doi.org/10.4036/I is.2016. R.o5

Lai, P. C. (2018). Security as an Extension to TAM Model: Consumers' Intention to Use a Single Platform E-Payment. Asia-Pacific Journal of Management Research and Innovation, $\mathrm{I}_{3}(3-4)$, IIO-II9

Lai, P. C., \& Ahmad, Z. A. (2014, April). Perceived Enjoyment of Malaysian consumers' intention to use a single platform E-payment. In International Conference on Liberal Arts ES Social Sciences., 25th-2gth April.

Lai, P. C., \& Zainal, A. A. (2015). Consumers' intention to use a single platform epayment system: A study among Malaysian internet and mobile banking users. Journal of Internet Banking and Commerce, 2O(I), I-I3.

Lee, M. C. (2009). Factors influencing the adoption of internet banking: An integration of TAM and TPB with perceived risk and perceived benefit. Electronic commerce research and applications, 8(3), I30-I4I.

Lee, S.; Lee, H. and Kim, S. (2007). Factors influencing the adoption behavior of mobile banking: a South Korean perspective, Journal of Internet Banking and Commerce, Vol. I2 No. 2

Lema, A. (2017). Factors influencing the adoption of mobile financial services in the unbanked population. Inkanyiso: Journal of Humanities and Social Sciences, $9(\mathrm{I})$, 37-5I.

Liao, Z., \& Wong, W. K. (2008). The determinants of customer interactions with internet-enabled e-banking services. Journal of the Operational Research Society, 59(9), I20I-I2IO.

Lockett, A., \& Littler, D. (1997). The adoption of direct banking services. Journal of marketing management, I3 (8), 79I-8II. 
Luarn, P., \& Lin, H. H. (2005). Toward an understanding of the behavioral intention to use mobile banking. Computers in buman behavior, $2 I(6)$, 873-89I.

Lule, I., Omwansa, T. K., \& Waema, T. M. (2012). Application of technology acceptance model (TAM) in m-banking adoption in Kenya. International journal of computing E ICT research, 6(I).

Lyman, T., \& Lauer, K. (2015). What Is Digital Financial Inclusion and Why Does It Matter? CGAP Blog, March, Io

Malhotra, P., \& Singh, B. (2007). Determinants of internet banking adoption by banks in India. Internet Research.

Manyika, J., Lund, S., Singer, M., White, O., \& Berry, C. (2016). Digital finance for all: Powering inclusive growth in emerging economies. McKinsey Global Institute, I-I5

Maragaoda, W. S. (2019). Customers' motivation to embrace digital banking in Sri Lanka: a case study of Sampath Bank PLC (Master's thesis).

Marakarkandy, B.; Yajnik, N., \& Dasgupta, C. (2017). Enabling internet banking adoption: An empirical examination with an augmented technology acceptance model (TAM).Journal of Enterprise Information Management.

Masinge, K. (2010). Factors influencing the adoption of mobile banking services at the Bottom of the Pyramid in South Africa. Master's Thesis, Gordon Institute of Business Science, Sandton, South Africa.

Mayer, R. C.; Davis, J. H., \& Schoorman, F. D. (1995). An integrative model of organizational trust. Academy of management review, 20 (3), 709-734.

McKnight, D. H., \& Chervany, N. L. (200I). What trust means in e-commerce customer relationships: An interdisciplinary conceptual typology. International journal of electronic commerce, 6(2), 35-59.

Md Nor, K., \& Pearson, J. M. (2008). An Exploratory Study Into the Adoption of Internet Banking in a Developing Country: Malaysia, Journal of Internet Commerce 7(I), 29-73. 
Metwally, E. K. (2013). An assessment of users' acceptance of Internet banking: An empirical case of Egypt. American Academic \& Scholarly Research Journal, $5(5), \mathbf{1} 32$.

Munir, A. R.; Idrus, M. S.; Kadir, R. A., \& Jusni, S. E. (2013). Acceptance of mobile banking services in Makassar: a technology acceptance model (TAM) approach. IOSR Journal of Business and Management, 7(6), 5259.

Nasri, W. (20II). Factors influencing the adoption of internet banking in Tunisia. International journal of business and management, 6(8), I43I6o.

Ndubisi, N. O., \& Jantan, M. (2003). Evaluating IS usage in Malaysian small and medium-sized firms using the technology acceptance model. Logistics information management.

Ndubisi, N. O., \& Sinti, Q. (2006). Consumer attitudes, system's characteristics and internet banking adoption in Malaysia. Management Research News.

Netherlands, Information Management, 40 (2), 54I-9.

Ng, A. W., \& Kwok, B. K. (2017). Emergence of Fintech and cybersecurity in a global financial centre: Strategic approach by a regulator. Journal of Financial Regulation and Compliance.

Ooi, K. B., \& Tan, G. W. H. (2016). Mobile technology acceptance model: An investigation using mobile users to explore smartphone credit card. Expert Systems with Applications, 59, 33-46.

Owoseni, O. O., \& Adeyeye, T. C. (20I4). An Empirical Assessment of Customers' Intention to Use Internet Banking in Nigeria. Research Journal of Finance and Accounting, 5(8), 40-46.

Ozili, P. K. (2018). Impact of digital finance on financial inclusion and stability. Borsa Istanbul Review, I8(4), 329-340.

Patel, K. J., \& Patel, H. J. (20I8). Adoption of internet banking services in Gujarat: An extension of TAM with perceived security and social influence. International Journal of Bank Marketing. 
Petrova, K. \& Yu, S. (2010). Sms banking: An exploratory investigation of the factors influencing future use. International journal of E-Services and mobile alications, 2 (3), 19-43.

Pikkarainen, T.; Pikkarainen, K.; Karjaluoto, H., \& Pahnila, S. (2004). Consumer acceptance of online banking: an extension of the technology acceptance model. Internet research.

Püschel, J.; Mazzon, J. A., \& Hernandez, J. M. C. (20I0). Mobile banking: proposition of an integrated adoption intention framework. International Journal of bank marketing.

Rahi, S.; Ghani, M., \& Ngah, A. (2018). A structural equation model for evaluating user's intention to adopt internet banking and intention to recommend technology. Accounting, 4(4), I39-152.

Ramdhony, D., \& Munien, S. (2013). An investigation on mobile banking adoption and usage: A case study of Mauritius. World, 3(3), 197-217.

Ramlugun, V. G., \& Issuree, H. (20I4). Factors determining mobile banking adoption in Mauritius. International Journal of Innovation Research $\mathcal{E}$ Development, 3(I), 193-202

Revels, J.; Tojib, D., \& Tsarenko, Y. (20I0). Understanding consumer intention to use mobile services. Australasian Marketing Journal, I8(2), 74-8o.

Riffai, M. M. M. A.; Grant, K., \& Edgar, D. (20I2). Big TAM in Oman: Exploring the promise of on-line banking, its adoption by customers and the challenges of banking in Oman. International journal of information management, $32(3), 239-250$.

Rotchanakitumnuai, S., \& Speece, M. (2003). Barriers to Internet banking adoption: a qualitative study among corporate customers in Thailand. International journal of bank marketing.

Rusu, R. F., \& Shen, K. N. (2012). An empirical study on e-banking acceptance in the United Arab Emirates (UAE). Journal of Electronic Banking Systems

Sánchez-Torres, J. A.; Sandoval, A. V., \& Alzate, J. A. S. (2018). E-banking in Colombia: factors favouring its acceptance, online trust and government support. International Journal of Bank Marketing. 
Sarstedt, M.; Ringle, C. M., \& Hair, J. F. (2017). Partial least squares structural equation modeling. Handbook of market research, 26(I), I-40.

Sayid, O.; Echchabi, A., \& Echchabi, H. A. A. A. (2012). Investigating mobile money acceptance in Somalia: An empirical study. Pakistan Journal of Commerce and Social Sciences (PJCSS), 6(2), 269-28I.

Schumacker, R. E., \& Lomax, R. G. (2004). A beginner's guide to structural equation modeling. Psychology press.

Scott, S. V.; Van Reenen, J., \& Zachariadis, M. (2017). The long-term effect of digital innovation on bank performance: An empirical study of SWIFT adoption in financial services. Research Policy, 46(5), 984-I004.

Sripalawat, J.; Thongmak, M., \& Ngramyarn, A. (20II). M-banking in metropolitan Bangkok and a comparison with other countries. Journal of computer information systems, $5 \mathrm{I}(3), 67-76$.

Sun, T. (2018). Balancing Innovation and Risks in Digital Financial InclusionExperiences of Ant Financial Services Group. In Handbook of Blockchain, Digital Finance, and Inclusion, 2, 37-43. Academic Press.

Susanto, A.; Lee, H.; Zo, H., \& Ciganek, A. P. (2013). User acceptance of Internet banking in Indonesia: initial trust formation. Information Development, 29(4), 309-322.

Tan, M. and Teo, T.S. (200o). Factors influencing the adoption of internet banking, Journal of the Association for Information Systems, I (I), I-42

Teo, T. S. H., \& Liu, J. (2007). Consumer trust in e-commerce in the United States, Singapore and China Omega, 35(I), 22-38.

Venkatesh, V. (2000). Determinants of perceived ease of use: Integrating control, intrinsic motivation, and emotion into the technology acceptance model. Information systems research, $I I(4), 342-365$.

Venkatesh, V., \& Bala, H. (2008). Technology acceptance model 3 and a research agenda on interventions. Decision sciences, 39(2), 273-315.

Venkatesh, V., \& Davis, F. D. (1996). A model of the antecedents of perceived ease of use: Development and test. Decision sciences, 27(3), 45I-48I. 
Venkatesh, V., \& Davis, F. D. (200o). A theoretical extension of the technology acceptance modelran: Four longitudinal field studies. Management science, $46(2)$, I86-204.

Venkatesh, V.; Morris, M. G.; Davis, G. B., \& Davis, F. D. (2003). User acceptance of information technology: Toward a unified view. MIS quarterly, $425-$ 478.

Wang, M.; Zhi, H., \& Li, X. (20I4). An empirical study of customer behavior online shopping in China. In Proceedings of the Seventh International Conference on Management Science and Engineering Management (177-I89). Springer, Berlin, Heidelberg.

Wang, Y. S.; Wang, Y. M.; Lin, H. H., \& Tang, T. I. (2003). Determinants of user acceptance of Internet banking: an empirical study. International journal of service industry management I4(5), 50I-519.

Wang, Y.S.; Lin, H.H. and Luarn, P. (2006). Predicting consumer intention to use mobile service, Information Systems Journal, 16 (2), I57-I79.

Wessels, L. \& Drennan, J. (2010). An investigation of consumer acceptance of mbanking. International journal of bank marketing, 28 (7), 547-568.

Widjana, M. A. (20II). Factors determining acceptance level of internet banking implementation. Journal of Economics, Business, \& Accountancy Ventura, I4(2).

Yiu, C. S.; Grant, K., \& Edgar, D. (2007). Factors affecting the adoption of Internet Banking in Hong Kong-implications for the banking sector. International journal of information management, 27(5), 336-35I.

Yousafzai, S. Y.; Pallister, J. G., \& Foxall, G. R. (2005). Strategies for building and communicating trust in electronic banking: A field experiment. Psychology \& Marketing, 22(2), I8I-20I.

Yousafzai, S., \& Yani-de-Soriano, M. (2012). Understanding customer-specific factors underpinning internet banking adoption. International journal of bank marketing, 30(I), 6o-8I. 


\section{نية المستهلك لتبني الخدمات المالية الرقمية في مصر: نموذج قبول التكنولوجيا الممتد

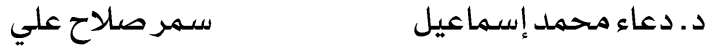 \\ د. دفوت عادل الشرقاوى
}

\section{ملخص البحث باللغة العربية}

يعتبر التمويل الرقمي أحد الركائز الهامة والداعمة للشمول المالي في مصر بالإضافة الي كونها قناة هامة في تقديم الخدمات

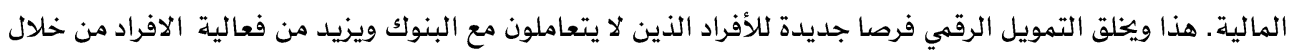

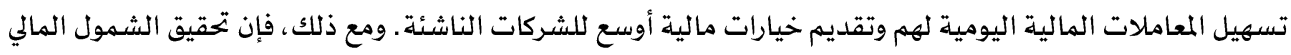

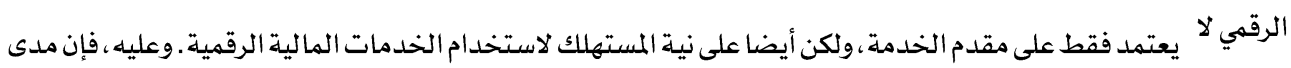

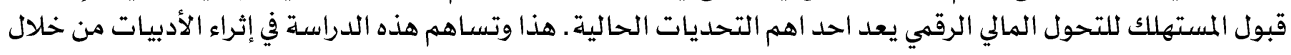

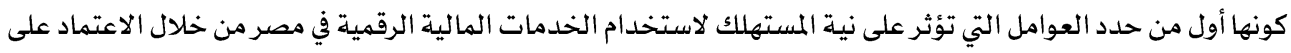

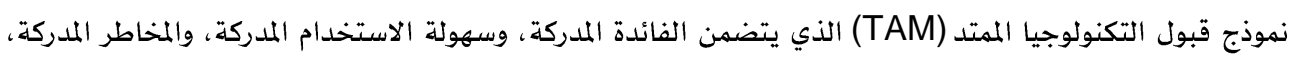
والتكلفة المدركة، والدعم الحكومي ، والثقة كعوامل رئيسية . وبناء علي ذلك تم تصميم الاستقصاء الالكتروني وتوزيعه علي

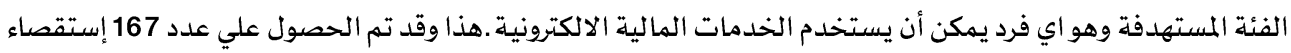

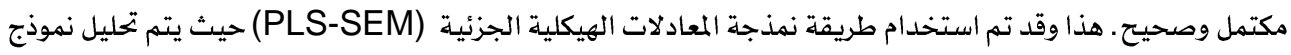

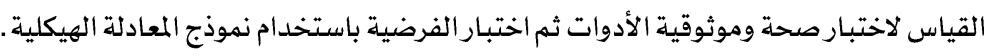

وقد توصلت النتائج أن الفائدة المدركة (PU) والثقة (TRU) لها تأثيرإيجابي كبيرعلى نية المستهلكين (INT) لاستخدام

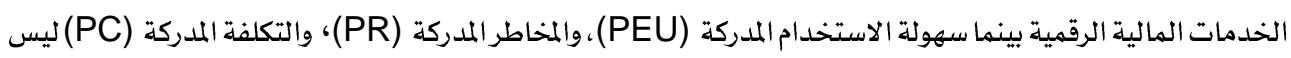

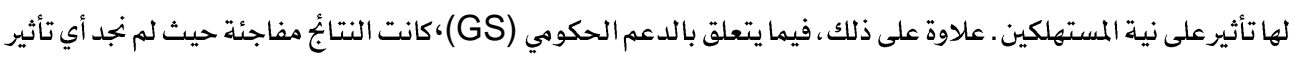

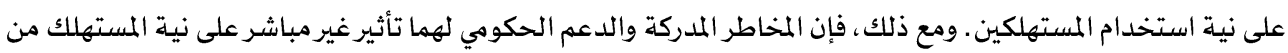
خلال تأثيرهما على ثقة المستهلكين، وبالتالي يمكن القول إن الثقة تلعب دورا وسيطا مهما' الكلمات الدالة: التمويل الرقمي، قبول المستهلك، نموذج قبول التكنولوجيا، نية التبني، الشمول المالي

\section{Suggested Citation according to APA Style}

Ismael, D. M.; Ali, S. S.; Elsharkawi, S. A. (202I). Consumer Intention to Adopt Digital Financial Services in Egypt: An Extended Technology AcceptanceModel.Journal of Alexandria University for Administrative Sciences, Faculty of Commerce, Alexandria University 58 (5),273-3II.

All rights reserved (c) 2021 